\title{
THE PRODUCTION EFFICIENCY AND SPECIFIC ENERGY CONSUMPTION DURING PROCESSING OF CORN EXTRUDATES WITH FRESH VEGETABLES ADDITION
}

\author{
Katarzyna Lisiecka ${ }^{\mathrm{a}}$, Agnieszka Wójtowicz ${ }^{\mathrm{b}}$ \\ ${ }^{a}$ Department of Thermal Technology and Food Process Engineering, University of Life Sciences in \\ Lublin, Głęboka 31, 20-612 Lublin, Poland, katarzyna.zelizko@ gmail.com ORCID 0000-0003-0659- \\ 8704 \\ ${ }^{\mathrm{b}}$ Department of Thermal Technology and Food Process Engineering, University of Life Sciences in \\ Lublin, Głęboka 31, 20-612 Lublin, Poland, agnieszka.wojtowicz@up.lublin.pl ORCID: 0000-0001- \\ 5981-6109 \\ *Corresponding author: e-mail: agnieszka.wojtowicz@up.lublin.pl

\begin{tabular}{|c|c|}
\hline ARTICLE INFO & ABSTRACT \\
\hline $\begin{array}{l}\text { Article history: } \\
\text { Received: Aprilr } 2019 \\
\text { Received in the revised form: } \\
\text { May } 2019 \\
\text { Accepted: June } 2019 \\
\end{array}$ & $\begin{array}{l}\text { The aim of the work was to determine the influence of screw speed and } \\
\text { variable amounts of fresh vegetable additives on selected aspects of } \\
\text { extrusion-cooking of corn-vegetable blends. Corn grit as a basic com- } \\
\text { ponent was supplemented with a fresh pulp of beetroot, carrot, leek and } \\
\text { onion in amounts of } 2.5-10 \% \text { in the recipe. The extrusion-cooking was }\end{array}$ \\
\hline $\begin{array}{l}\text { Key words: } \\
\text { corn, } \\
\text { extrusion-cooking, } \\
\text { vegetable, } \\
\text { efficiency, } \\
\text { SME }\end{array}$ & $\begin{array}{l}\text { carried out using a single-screw extruder in the temperature range } 120- \\
145^{\circ} \mathrm{C} \text { and extrudates were formed into directly expanded snacks. Two } \\
\text { indicators were measured: the production efficiency }(Q) \text { and the spe- } \\
\text { cific mechanical energy ( } S M E) \text { consumption. As a result of the findings } \\
\text { it was noted that the rotational speed of the extruder's screw showed } \\
\text { a greater impact on both production efficiency and } S M E \text { as compared } \\
\text { to the variable amounts of applied additives. A tendency to increased } \\
\text { efficiency and specific mechanical energy consumption was observed } \\
\text { along with the increase of screw speed during processing. The highest } \\
\text { production efficiency was observed if fresh leek and onion were used } \\
\text { as additives and the highest extrusion speed screw was applied. The } \\
\text { largest specific energy consumption was noted during the extrusion- } \\
\text { cooking of blends containing fresh carrot and onion addition at high } \\
\text { screw speed. }\end{array}$ \\
\hline
\end{tabular}

\section{Introduction}

Vegetables are very important sources of vitamins, micro- and macroelements as well as fiber in a daily diet. Consumption of fresh or minimally treated vegetables may avoid civilization diseases, such as cancer, cardiovascular disease or others. However, widespread dissemination of this knowledge does not increase the consumption of fruit and vegetables (Rekhy et al., 2017; Ocean et al., 2019). The most typical long-term preservation for vegetables is freezing, but it being an extremely power-consuming process (Korotkiy et al., 2016). Moreover, the findings for frozen vegetables demonstrate that transformation from its natural 
state into frozen ones lead to negative products evaluations by consumer (Connell et al., 2018). While among the drying methods, lyophilization shows best effects for vegetable properties. However, this method is time and energy consuming (Yu et al., 2018). The most appropriate trend seems to be limiting treatment and using or eating the fresh or blanched vegetables to avoid losses of the valuable components and to keep its natural colour, flavour and texture.

Extrusion-cooking - a process using the high pressure and short time treatment - is the technology which creates the possibility of typical products' fortification, like e.g. snacks, with nutrient-rich ingredients (Wójtowicz, 2018). Extrusion-cooking have a lot of advantages, for example wide range of extrudates shapes, destruction of undesirable antinutritional factors, enhance the digestibility and makes it possible to achieve the desired texture (Shah et al., 2016). One of the most important classification of single screw extruders is the classification due to the $\mathrm{L} / \mathrm{D}$ ratio (ratio of screw length to its diameter). $\mathrm{L} / \mathrm{D}=9-11$ is typically used for pasta press, 12-15 for high-pressure extruders, 15-30 for low-shear extruders, 15-25 for high-shear extruders and 3-5 for collet-type extruders to produce snacks (Harper, 1981; Mercier et al., 1989). From the literature it can be found that the specific energy consumption of the extrusion-cooking process in the case of single screw extrusion is dependent on the raw materials used, moisture content and screw speed appplied. However, it should be noticed that the extrusion process is preceded by other processes, which may include grinding, mixing, moistening or steaming, that may influence on the total specific energy consumption of processing (Marks, 2010; Matysiak et al., 2018).

The most commonly used raw materials for ready to eat extrudates are cereals or pseudocereals, mainly corn, rice or wheat, rich in carbohydrates, enabling formation of a porous structure of the extruded snacks. However, these types of basic raw materials are not rich enough in nutrition compounds (Pęksa et al., 2016). So, it is possible to improve the nutritional value of extrudates by the addition of various components such as vegetables, fruits, herbs, etc. These additives are mainly used in a powdered state, but there is limited information about processing of extrudates supplemented with fresh vegetable additives. So, some tests have been made to check the possibility of using fresh vegetable pulps as valuable additives which haven't been air-dried or freeze-dried before the extrusion, what result in reducing the total energy requirements of the whole production process.

\section{Objective, scope and methods of research}

The objective of the research was to evaluate the production efficiency and the specific energy consumption during processing of snacks with the single-screw extrusion-cooking. The main assumption was to obtain ready to eat corn snacks with possibly the largest amounts of fresh vegetables and to assess some aspects of the production process as the production efficiency and specific energy consumption.

The recipe of extrudates was based on corn grits (supplied by Lubella Sp. z o.o. Sp. K., Lublin, Poland) and vegetable additives, such as beetroot, carrot, leek and onion (commercially available on the market). Corn grit (as a control sample) and blends with variable amount of additives as replacement of the corresponding amount of the base ingredient in the recipe were prepared. Two independent variables were used in the experiment: the content of vegetable additives $(2.5,5.0,7.5$ and $10.0 \%$ as a replacement of corn grits in the recipe) 
The production efficiency...

and the speed screw $(80,100$ and $120 \mathrm{rpm})$ during processing. In the first step, fresh vegetables were cleaned with tap water, removed from inedible parts, drained, cut into small pieces and then ground using a laboratory grinder (Grindomix GM 200, Retsch, Germany). In the next step, the ground additives were mixed with corn grits and left to rest for $2 \mathrm{~h}$ to equilibrate the moisture content brought by the fresh additives in the mixture. The moisture content of corn was $13.0 \%$ and for prepared blends ranged at $15.1 \%-20.8 \%, 14.2 \%-21.0 \%, 14.4 \%$ $20.0 \%$ and $14.3 \%-18.6 \%$ if beetroot, carrot, leek and onion were added, respectively. Extrusion-cooking was done using a TS-45 single-screw extruder-cooker (Z.M.Ch. Metalchem, Gliwice, Poland) with a ratio of the screw length to its diameter of $\mathrm{L} / \mathrm{D}=12$ at variable screw speeds with a $3 \mathrm{~mm}$ circular forming die. The temperature in the first, second and third section of the extruder was set at $120^{\circ} \mathrm{C}-145^{\circ} \mathrm{C}-130^{\circ} \mathrm{C}$, respectively. Just after leaving a forming die the extrudates were cut with a rotary cutting knife for $30 \mathrm{~mm}$ long crisps. After forming, the snacks were cooled down to ambient temperature and collected as ready for direct consumption. Moreover, final extrudates characterized with the moisture content not exceeding $13 \%$ and the water activity below 0.56 .

Evaluation of the extrusion-cooking efficiency $(Q)$, as a ratio of the extrudate mass obtained in a time unit, was determined according to the formula proposed by Matysiak et al. (2018):

$$
Q=\frac{m}{t}\left(\mathrm{~kg} \mathrm{~h}^{-1}\right)
$$

where:

$Q \quad$ - production efficiency,

$m \quad$ - mass of the obtained snacks, $(\mathrm{kg})$

$t \quad-$ measurement time, (h)

Specific mechanical energy $(S M E)$ as a power consumption was determined according to the formula presented by Kręcisz et al. (2016):

$$
S M E=\frac{n * P * O}{n_{\max } * 100 * Q}\left(\mathrm{kWh} \mathrm{kg}^{-1}\right)
$$

where:

$$
\begin{array}{ll}
S M E & \text { - specific mechanical energy, } \\
n & \text { - screw rotations, }(\mathrm{rpm}) \\
P & \text { - electric power, }(\mathrm{kW}) \\
O & \text { - engine load, }(\%) \\
n_{\max } & - \text { maximum screw rotations, }(\mathrm{rpm}) \\
Q & \text { - production efficiency, }\left(\mathrm{kg} \mathrm{h}^{-1}\right)
\end{array}
$$

Statistical analysis was carried out using a Statistica 13.3 software (StatSoft, USA). The data were analyzed with the response surface (RSM) models and plots to analyze interactions of two independent factors, additionally regression equations and regression coefficients have been found. A second-order polynomial model (Eq. 3) was defined to fit the responses:

$$
Y=\beta_{0}+\beta_{1} X_{1}+\beta_{2} X_{2}+\beta_{11}\left(X_{1}\right)^{2}+\beta_{12} X_{1} X_{2}+\beta_{22}\left(X_{2}\right)^{2}
$$


where: $Y$ is the response obtained by the fitted model and $\beta_{0}$ is the model intercept. $\beta_{1}, \beta_{2}$ are the linear coefficients, $\beta_{12}$ is the interaction coefficient, and $\beta_{11}, \beta_{22}$ are the quadratic coefficients. An analysis of variance was carried out with ANOVA at the level of confidence $\alpha=0.05$.

\section{Results and analysis}

The results of the extrusion-cooking production efficiency during processing of corn extrudates with addition of different vegetables under various screw speed is presented in Fig. 1. An increased process output was noticed for all the tested samples with increased the rotation screw speed. Due to the effect of additive amount it have been found some differences and increasing efficiencies were observed for extrudates supplemented with beetroot (Fig. 1a), leek (Fig. 1c) and onion up to $5.0 \%$ (Fig. 1d). Further supplementation with beetroot, leek and onion affected slight decrease in processing output.

a)
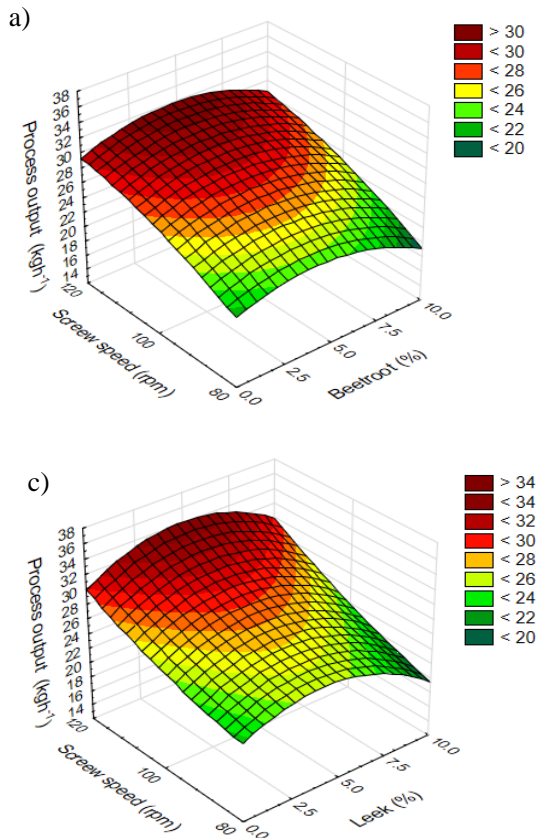
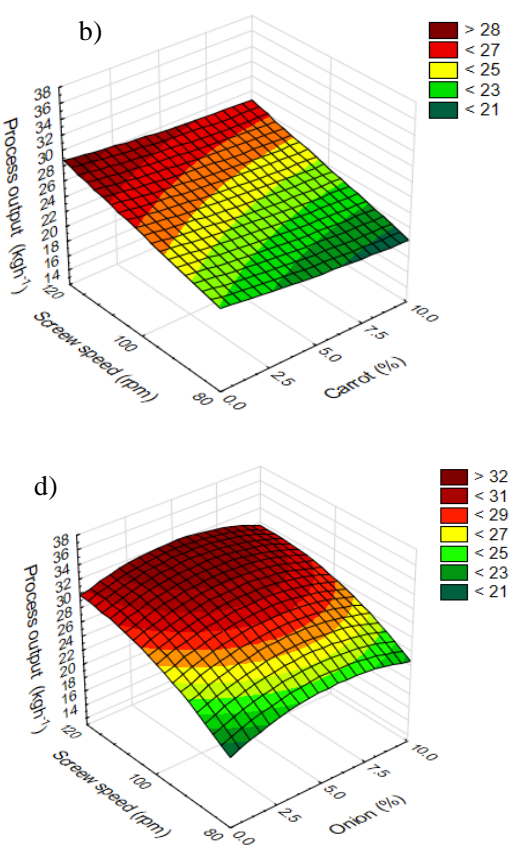

Figure 1. Production efficiency results during the extrusion-cooking of corn extrudates with addition various vegetables: a) beetroot, b) carrot, $c$ ) leek, d) onion

When a carrot was used as an additive, the constant decrease of efficiency was observed during processing of supplemented extrudates (Fig. 1b), also for this additive the lowest efficiency was observed along with the amount of vegetable additive as well as the screw 
The production efficiency...

speed applied. During the production of corn instant grits with using various screw speeds of single screw extruder, Kręcisz (2016) found similar tendency to increasing processing efficiency in respect to increased screw speed. Similar relationships have been observed by Kręcisz et al. (2015) for corn-rice instant grits produced with using screw speeds of 80,100 and $120 \mathrm{rpm}$, however, the results showed that blends with higher rice flour content characterized with higher process efficiency.

The highest production efficiency (above $34 \mathrm{~kg} \mathrm{~h}^{-1}$ ) was observed for corn extrudates with addition of 2.5 and $5.0 \%$ of leek and for snacks with $5.0 \%$ of beetroot and onion produced with applying the $120 \mathrm{rpm}$ of screw speed. With the highest content of fresh vegetables, the production efficiency decreased what would be the effect of the increased moisture content of processed blends. The lowest production efficiency $\left(19.2 \mathrm{~kg} \mathrm{~h}^{-1}\right)$ was observed for cornbeetroot extrudates with $10.0 \%$ of additive with using a screw speed of $80 \mathrm{rpm}$. High determination coefficients characterized good model fitting due to the production efficiency if beetroot, carrot and leek were found in the experiment (Table 1). The analysis of variance (Table 2) showed that the content of vegetable additives had a significant effect on production efficiency only for corn extrudates with addition of beetroot $(p=0.000, r=0.93)$ and leek ( $p=0.043, \mathrm{r}=0.97)$, which, moreover, characterized similar responses from RSM plots. In the same time, the screw speed had a significant effect on production efficiency of corn-based blends with beetroot $(p=0.000, \mathrm{r}=0.93)$, carrot $(p=0.000, \mathrm{r}=0.91)$ and onion $(p=0.000$, $\mathrm{r}=0.88$ ). The most significant effect, due to the highest value of F-test, according to the effect of the amount of additive was observed if beetroot was applied as additive, but if the effect of screw speed was analyzed, the most significant effect was found for corn-carrot blends.

Table 1.

Multiple regression equations and determination coefficients of production efficiency and specific energy consumption models for various additives in extruded blends

\begin{tabular}{lcccc}
\hline $\begin{array}{l}\text { Addi- } \\
\text { tive }\end{array}$ & $\begin{array}{c}\text { Depen- } \\
\text { dent } \\
\text { variable }\end{array}$ & Regression equation & $\mathrm{R}^{2}$ \\
\hline Beetroot & $\begin{array}{c}Q \\
S M E\end{array}$ & $\begin{array}{c}Q=-19.5806+0.69 C A+0.7236 S S-0.1207 C A^{2}+0.0036 C A \cdot S S-0.0026 S S^{2} \\
S M E=0.2657-0.003 C A-0.0012 S S+0.0008 C A^{2}-5.93 \mathrm{E}^{-5} C A \cdot S S+9.89 \mathrm{E}^{-6} 2\end{array}$ & 0.86 \\
& $\begin{array}{c}Q \\
\text { Carrot }\end{array}$ & $Q$ & $Q=10.3063-0.5266 C A+0.168 S S+0.0155 C A^{2}+0.0014 C A \cdot S S-0.0001 S S^{2}$ & 0.82 \\
& $S M E$ & $S M E=0.1168+0.0027 C A+0.0015 S S-3.0735 \mathrm{E}^{-5} C A^{2}-2.78 \mathrm{E}^{-5} C A \cdot S S-1.94 \mathrm{E}^{-6} S S^{2}$ & 0.59 \\
\hline \multirow{2}{*}{ Leek } & $Q$ & $Q=30.008+0.7184 C A-0.2748 S S-0.1664 C A^{2}+0.0079 C A \cdot S S+0.0023 S S^{2}$ & 0.94 \\
& $S M E$ & $S M E=-0.0225+0.0028 C A+0.0045 S S+0.001 C A^{2}-0.0001 C A \cdot S S-1.7321 \mathrm{E}^{-5} S S^{2}$ & 0.59 \\
\hline \multirow{2}{*}{ Onion } & $Q$ & $Q=-44.1897+1.5022 C A+1.2132 S S-0.0997 C A^{2}-0.0043 C A \cdot S S-0.005 S S^{2}$ & 0.77 \\
& $S M E$ & $S M E=0.5777-0.0073 C A-0.0077 S S+0.0002 C A^{2}+2.61 \mathrm{E}^{-5} C A \cdot S S+4.26 \mathrm{E}^{-5} S S^{2}$ & 0.66 \\
\hline$Q-$ process efficiency; $S M E-$ specific energy consumption; $C A-$ content of the additive; $S S-$ screw speed $^{2}$
\end{tabular}

Fig. 2 presents the effect of processing variable conditions on specific mechanical energy requirements during the extrusion-cooking of various corn-based extrudates. The specific energy consumption during the extrusion-cooking relates to the thermo-mechanical starch 
conversion. Therefore, in the case of higher $S M E$ it can be manifested better starch gelatinization of expanded products (Pardhi et al., 2019).

With the increased rotation screw speed, it has been noticed an increased SME during processing of extrudates with fresh beetroot (Fig. 2a), carrot (Fig. 2b) and onion (Fig. 2d). The range of $S M E$ varied from 0.21 to $0.27 \mathrm{kWh} \mathrm{kg}^{-1}$. The lowest specific energy consumption was observed during processing of blends with $7.5 \%$ and $10.0 \%$ of onion and at screw speeds of 80 and $100 \mathrm{rpm}$. Low $S M E$ values were observed also if beetroot and leek were added in amounts of 5.0 and $7.5 \%$ in the recipe. The greatest values were noted for corn extrudates without additives which means that addition of fresh vegetables reduced the energy requirements during the extrusion-cooking. This phenomenon is probably because of the higher initial moisture content of blends, what is reducing the mechanical shearing intensity and thus the specific energy consumption during processing. Wherein, the content of vegetable additive had an insignificant effect on $S M E$ only for snack with onion, it was noted that screw speed had significant effect on SME of corn snacks with almost all additives used, except of leek (Table 2).
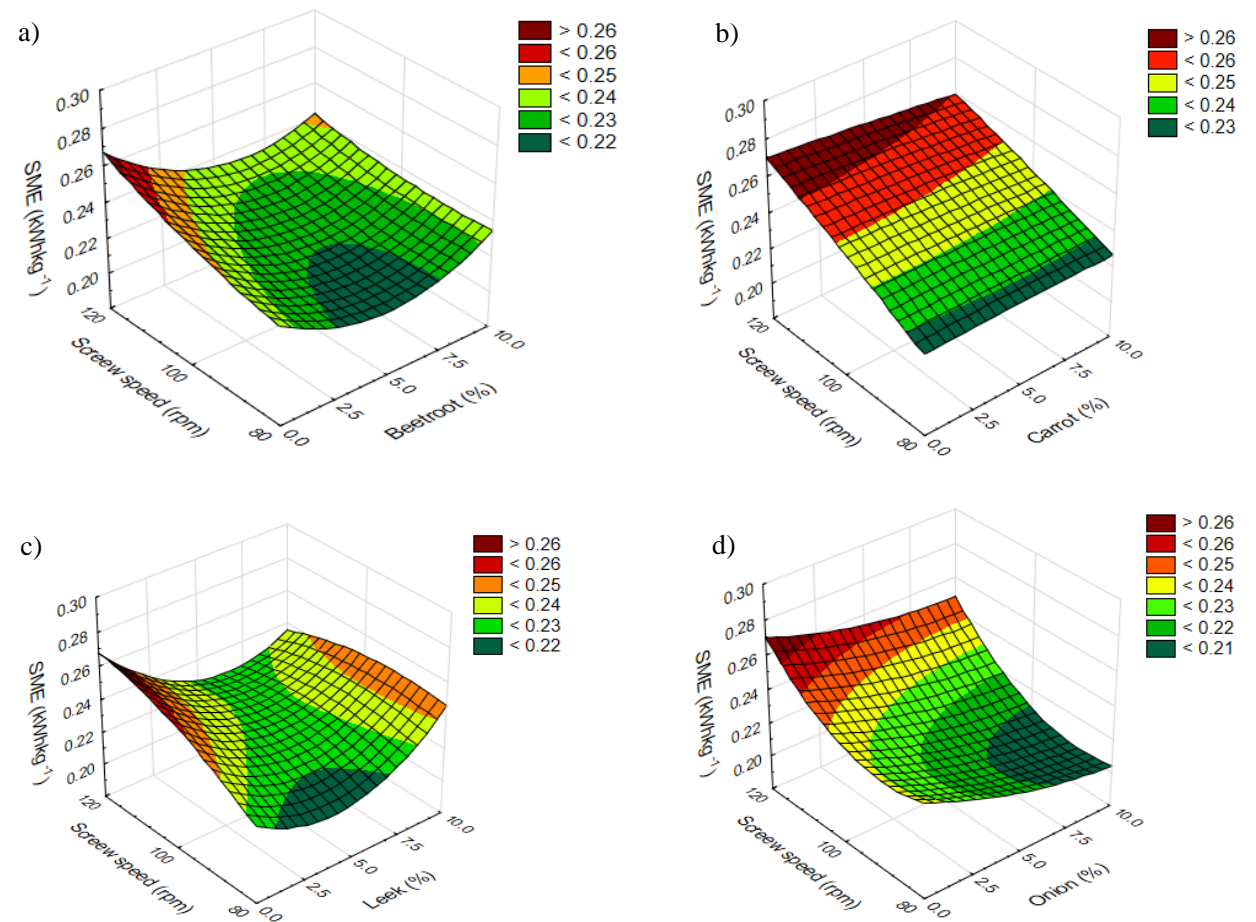

Figure 2. The effect of processing variable conditions on specific mechanical energy during the extrusion-cooking of corn extrudates with addition of fresh vegetables: a) beetroot, b) carrot, c) leek, d) onion 
The production efficiency...

Similar observations were reported by Ali et al. (2016a) for the extruded maize-chickpea flour mixture and the obtained values of $S M E$ ranged from 0.10 to $0.23 \mathrm{kWh} \mathrm{kg}^{-1}$. Other researchers (Baik et al., 2004) have noted that the growth of $S M E$ was caused by the fact that more energy is supplied in the aim to obtain higher screw rotations. What is more, the screw speed causes an increase in $S M E$ input attributed to the increase in shear rate with increased screw speed (Altan et al., 2008). The results presented by Singha and Muthukumarappan (2017) for extrudates with addition of apple pomace (from 0 to 20\%) ranged from 0.05 to $0.16 \mathrm{kWh} \mathrm{kg}^{-1}$. They observed that $S M E$ decreased with increased level of apple pomace up to a certain extent. This relationship was assigned progressively by the decreasing of starch content. During the extrusion-cooking of maize-mung bean flour mixture values of $S M E$ reported by Ali et al. (2016b) were between 0.14 and $0.25 \mathrm{kWh} \mathrm{kg}^{-1}$. The greatest value of $S M E$ was noted in this research for samples processed at low feed moisture, low barrel temperature and high screw speed. Considering the F-test results, in most cases the rotational speed of the extruder's screw had a greater impact on $S M E$ during snacks processing than the content of vegetable additives (Table 2). However, Matysiak et al. (2018) reported that for the tested extruded snack pellets moistened up to $32-34 \%$ the rotational speed ranged 20-60 rpm had a smaller influence on $S M E$ as compared with the moisture content.

Table 2.

Results of analysis of variance of the effects of processing conditions on process efficiency and specific energy consumption during the extrusion-cooking

\begin{tabular}{|c|c|c|c|c|c|c|c|c|c|c|}
\hline 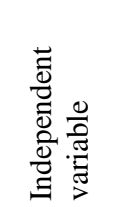 & 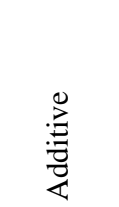 & 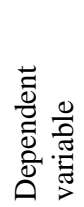 & 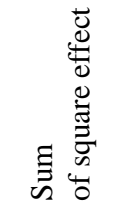 & 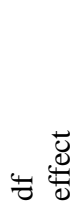 & 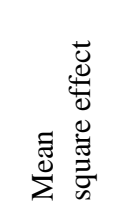 & 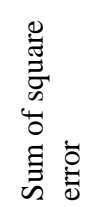 & to & 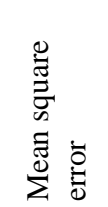 & $\frac{\overrightarrow{v_{0}}}{\frac{1}{L}}$ & 2 \\
\hline \multirow{8}{*}{$\begin{array}{l}\text { Content } \\
\text { of the } \\
\text { additive } \\
(\%)\end{array}$} & \multirow{2}{*}{ beetroot } & $Q$ & 404.610 & 4 & 101.15 & 292.90 & 40 & 7.322 & 13.814 & $0.000 *$ \\
\hline & & SME & 0.005 & 4 & 0.001 & 0.009 & 40 & 0.0002 & 5.678 & $0.001 *$ \\
\hline & \multirow{2}{*}{ carrot } & $Q$ & 66.812 & 4 & 16.703 & 310.51 & 40 & 7.603 & 2.151 & 0.092 \\
\hline & & $S M E$ & 0.006 & 4 & 0.001 & 0.017 & 40 & 0.0004 & 3.365 & $0.018 *$ \\
\hline & \multirow{2}{*}{ leek } & $Q$ & 167.380 & 4 & 41.845 & 614.95 & 40 & 15.370 & 2.722 & $0.043 *$ \\
\hline & & $S M E$ & 0.005 & 4 & 0.002 & 0.101 & 40 & 0.0003 & 5.062 & $0.002 *$ \\
\hline & \multirow{2}{*}{ onion } & $Q$ & 106.540 & 4 & 26.635 & 614.07 & 40 & 15.350 & 1.735 & 0.161 \\
\hline & & $S M E$ & 0.006 & 4 & 0.001 & 0.027 & 40 & 0.0007 & 2.094 & 0.099 \\
\hline \multirow{8}{*}{$\begin{array}{l}\text { Screw } \\
\text { speed } \\
\text { (rpm) }\end{array}$} & \multirow{2}{*}{ beetroot } & $Q$ & 485.708 & 2 & 242.850 & 211.81 & 42 & 5.043 & 48.156 & $0.000^{*}$ \\
\hline & & SME & 0.004 & 2 & 0.002 & 0.010 & 42 & 0.002 & 8.416 & $0.001^{*}$ \\
\hline & \multirow{2}{*}{ carrot } & $Q$ & 274.340 & 2 & 137.170 & 102.98 & 42 & 2.452 & 55.950 & $0.000^{*}$ \\
\hline & & SME & 0.012 & 2 & 0.006 & 0.012 & 42 & 0.0003 & 20.180 & $0.000 *$ \\
\hline & \multirow{2}{*}{ leek } & $Q$ & 537.660 & 2 & 268.830 & 244.66 & 42 & 5.825 & 46.150 & $0.000 *$ \\
\hline & & $\widetilde{S M E}$ & 0.002 & 2 & 0.001 & 0.013 & 42 & 0.0003 & 2.851 & 0.069 \\
\hline & \multirow{2}{*}{ onion } & $Q$ & 498.790 & 2 & 249.400 & 221.82 & 42 & 5.281 & 47.220 & $0.000 *$ \\
\hline & & SME & 0.016 & 2 & 0.008 & 0.018 & 42 & 0.0004 & 18.560 & $0.000 *$ \\
\hline
\end{tabular}

* significant effect at $\alpha=0.05$ 


\section{Conclusions}

With regard to the obtained results, the following conclusions were established:

1. The most efficient production was the extrusion-cooking of corn extrudates with the addition of fresh leek and onion at the highest rotation screw speed.

2. The lowest specific energy consumption was observed during the extrusion-cooking of corn-onion blends, especially at low screw speed.

3. Generally, values of F-test showed the higher effects of the extruder's screw speed on production efficiency and $S M E$ as compared to the content of fresh vegetables in cornbased blends.

\section{References}

Ali, S., Singh, B., Sharma, S. (2016a). Development of high-quality weaning food based on maize and chickpea by twin-screw extrusion process for low-income populations. Journal of Food Process Engineering, 40, 1-10.

Ali, S., Singh, B., Sharma, S. (2016b). Response surface analysis and extrusion process optimization of maize-mung bean based instant weaning food. International Journal of Food Science and Technology, 51(10), 2301-2312.

Altan, A., McCarthy, M. L., Maskan, M. (2008). Evaluation of snack foods from barley-tomato pomace blends by extrusion processing. Journal of Food Engineering, 84(2), 231-242.

Baik, B. K., Powers, J., Nguyen, L. T. (2004). Extrusion of regular and waxy barley flours for production of expanded cereals. Cereal Chemistry, 8, 94-99.

Connell, P. M., Finkelstein, S. R., Scott, M. L., Vallen, B. (2018). Negative associations of frozen compared with fresh vegetables. Appetite, 127, 296-302.

Harper, J. M. (1981). Extrusion of Foods. CRC Press, Boca Raton, FL, USA.

Korotkiy, I. A., Korotkaya, E. V., Kireev, V. V. (2016). Energy efficiency analysis of the sea buckthorn (hippophae rhamnoides) fruits quick freezing. Foods \& Raw Materials, 4(1), 110-120.

Kręcisz, M. (2016). Energy consumption during production of corn extrudates in relation to the process parameters. Agricultural Engineering, 20(2), 125-131.

Kręcisz, M., Wójtowicz, A., Oniszczuk, A. (2015). Effect of selected parameters on process efficiency and energy consumption during the extrusion-cooking of corn-rice instant grits. Agriculture and Agricultural Science Procedia, 7, 139-145.

Marks, N. (2010). The impact of humidity on the direct energy consumption in the process of grinding rye and triticale grains. Agricultural Engineering, 7(125), 125-130.

Matysiak, A., Wójtowicz, A., Oniszczuk, T. (2018). Process efficiency and energy consumption during the extrusion of potato and multigrain formulations. Agricultural Engineering, 22(2), 49-57.

Mercier, C., Linko, P., Harper, J. M. (1989). Extrusion Cooking. American Association of Cereal Chemists, St. Paul, MN, USA.

Ocean, N., Howley, P., Ensor, J. (2019). Lettuce be happy: A longitudinal UK study on the relationship between fruit and vegetable consumption and well-being. Social Science\&Medicine, 222, 335-345.

Pardhi, S. D., Singh, B., Nayik, G. A., Dar, B.N. (2019). Evaluation of functional properties of extruded snacks developed from brown rice grits by using response surface methodology. Journal of the Saudi Society of Agricultural Sciences, 18(1), 7-16.

Pęksa, A., Kita, A., Carbonell-Barrachina, A., Miedzianka, J., Kolniak-Ostek, J., Tajner-Czopek, A., Rytel, E., Siwek, A., Miarka, D., Drożdż, W. (2016). Sensory attributes and physicochemical features of corn snacks as affected by different flour types and extrusion conditions. LWT-Food Science Technology, 72, 26-36. 
The production efficiency...

Rekhy, R., Khan, A., van Ogtrop, F., McConchie, R. (2017). Consumer evaluation of 'Veggycation ${ }^{\circledR}$ ', a website promoting the health benefits of vegetables. Health Promotion Journal of Australia, 28, 21-29.

Shah, F. U. H., Sharif, M. K., Butt, M. S., Shahid, M. (2016). Development of protein, dietary fiber, and micronutrient enriched extruded corn snacks. Journal of Texture Studies, 48, 221-230.

Singha, P., Muthukumarappan, K. (2017). Effects of processing conditions on the system parameters during single screw extrusion of blend containing apple pomace. Journal of Food Process Engineering, 40(4), 1-11.

Wójtowicz, A. (2018). Ekstruzja - wybrane aspekty techniczne i technologiczne. Zeszyty Problemowe Postępów Nauk Rolniczych, 595,131-144 (in Polish).

Yu, H., Bai, A., Yang, X., Wang, Y. (2018). Electrohydrodynamic drying of potato and process optimization. Journal of Food Processing \& Preservation, 42(2), 1-9.

\section{WYDAJNOŚĆ PROCESU I JEDNOSTKOWE ZAPOTRZEBOWANIE ENERGII MECHANICZNEJ PODCZAS WYTWARZANIA EKSTRUDATÓW KUKURYDZIANYCH Z DODATKIEM ŚWIEŻYCH WARZYW}

Streszczenie. Celem pracy było określenie wpływu prędkości ślimaka i zmiennych ilości świeżych dodatków warzywnych na wybrane aspekty ekstruzji mieszanek kukurydziano-warzywnych. Grys kukurydziany jako podstawowy składnik uzupełniono dodatkiem pulpy ze świeżych buraków, marchwi, pora i cebuli w ilości 2,5-10,0\% receptury. Ekstruzję prowadzono z zastosowaniem jednoślimakowego ekstrudera $\mathrm{w}$ zakresie temperatury $120-145^{\circ} \mathrm{C}$, zaś ekstrudaty formowano do postaci bezpośrednio ekspandowanych przekąsek. Badano dwa wskaźniki: wydajność produkcji $(Q)$ i specyficzne zapotrzebowanie energii mechanicznej $(S M E)$. W wyniku przeprowadzonych badań zauważono, że prękość obrotowa ślimaka ekstrudera wykazała większy wpływ zarówno na wydajność procesu, jak i na $S M E$ w porównaniu ze zmienną ilością zastosowanych dodatków. Zaobserwowano tendencję do zwiększonej wydajności i zapotrzebowania energii mechanicznej wraz ze wzrostem prędkości obrotowej ślimaka podczas ekstruzji. Najwyższą wydajność procesu zaobserwowano, gdy jako dodatki zastosowano świeży por i cebulę, zaś ekstruzję prowadzono przy zastosowaniu najwyższej prędkości ślimaka. Największe jednostkowe zapotrzebowanie energii odnotowano podczas ekstruzji mieszanek zawierających dodatek świeżej marchwi i cebuli przy wysokich obrotach ślimaka ekstrudera.

Słowa kluczowe: kukurydza, ekstruzja, warzywa, wydajność, $S M E$ 